\title{
VASCULAR EPIPHYTES IN A REMNANT OF SEASONAL SEMIDECIDUOUS FOREST IN THE ZONA DA MATA, STATE OF MINAS GERAIS, BRAZIL
}

\author{
EPÍFITAS VASCULARES EM UM REMANESCENTE DE FLORESTA ESTACIONAL \\ SEMIDECIDUAL NA ZONA DA MATA, MINAS GERAIS, BRASIL
}

\author{
Daniel Elias Ferreira BARBOSA ${ }^{1}$; Geicilaine Alves BASÍLIO'; \\ Fernando Rodrigues da SILVA ${ }^{1}$; Luiz MENINI NETO ${ }^{1}$
}

1. Centro de Ensino Superior de Juiz de Fora, Campus Arnaldo Janssen, Juiz de Fora, MG, Brasil. daninhofb@yahoo.com.br

\begin{abstract}
This study was performed in a remnant of Seasonal Semideciduous Forest at Fazenda Fortaleza de Sant'Anna, in the municipality of Chácara, Minas Gerais, Brazil (22.0129S, 43.8628W), in an area of ca. 1 ha, via monthly expeditions throughout the year 2012. We found 91 species of vascular epiphytes, distributed in 44 genera and 12 families. The richest families were Orchidaceae (35 spp.), Bromeliaceae (18 spp.), Polypodiaceae (10 spp.), Piperaceae (nine spp.) and Araceae (seven spp.). Two species were recorded for the first time in Minas Gerais: Rodriguezia sticta and Stelis oligantha (Orchidaceae). Rhipsalis oblonga (Cactaceae) was recollected in the state after about 100 years without records. Four species are cited in the list of endangered plants in Minas Gerais: Nematanthus crassifolius (Gesneriaceae) and Cattleya bicolor (Orchidaceae) are in the category "Vulnerable" (VU), Nidularium azureum (Bromeliaceae) and Pleurothallis pectinata (Orchidaceae) are "Critically Endangered" (CR). Nidularium azureum is also cited as CR in the Red Book of Brazilian Flora. Most species were classified as characteristic holoepiphytes and anemochory was the most frequent dispersion syndrome.
\end{abstract} Chácara.

KEYWORDS: Atlantic Forest. Biodiversity. Conservation. Fazenda Fortaleza de Sant'Anna. Municipality of

\section{INTRODUCTION}

The Atlantic Forest is one of the world hotspots of biodiversity due to the large number of plants and animals, including many endemics (MYERS et al., 2000). About $11 \%$ of its original area exists today (RIBEIRO et al., 2009), where ca. 15,800 plant species occur, a high percentage of which are threatened with extinction (STEHMANN et al., 2009).

In Minas Gerais (MG), the original forest cover remained little altered until the beginning of the nineteenth century, when the coffee crop was responsible for a great impact on the natural landscape (VALVERDE, 1958). Menini Neto et al. (2009b) highlighted that the majority of existing vegetation remnants is composed of montane or high montane forests, "campos de altitude" and "campos rupestres", which are found only in areas of difficult access.

The few studies or non-existence of biological surveys in many regions of MG hinders the evaluation of these areas and consequently, the establishment of concrete actions to conserve biodiversity (DRUMMOND et al., 2009). Specific studies concerning the epiphytic flora are concentrated in the Southern Region of Brazil, with few for the Southeastern Region (KERSTEN, 2010) and even fewer in MG (WERNECK; ESPÍRITOSANTO, 2002; ALVES et al., 2008; MENINI NETO et al., 2009a).

To contribute to the knowledge of epiphytic flora in Minas Gerais state and to reduce the current knowledge gaps in the Southeastern Region, the present study was conducted in a remnant of Seasonal Semideciduous Forest in Zona da Mata of MG, in the municipality of Chácara, part of the "Corredor Sudeste" in an area considered of "Very High" biological importance by Drummond et al. (2005).

The aims of the study were to survey the species of vascular epiphytes, indicate the ecological category and dispersal syndromes and discuss the importance of forest remnants in the conservation of epiphytic species in the Zona da Mata of Minas Gerais.

\section{MATERIAL AND METHODS}

The study was performed in a remnant of Seasonal Semideciduous Forest that lies in Fazenda Fortaleza de Sant'Anna (FFS) (22,0129S, $43,8628 \mathrm{~W}$ ), in the Zona da Mata, MG, between the municipalities of Chácara, Coronel Pacheco, Goianá and São João Nepomuceno, in a region locally known as Serra da Babilônia (Figure 1). The forest 
has several watercourses that integrate the basin of Rio Paraíba do Sul. The altitude is between 800 and 900 m.s.m. and the area that surrounds the forest is occupied by crops and pasture (PREA, 2012). The climate of region is $\mathrm{CwB}$ according to the Köppen classification, with dry and cold winters and wet and mild summers (CETEC, 1983).
Monthly collections were conducted during 2012 (with one pilot collection in July 2011), via the "método de caminhamento" (FILGUEIRAS et al., 1994), in the region belonging to the municipality of Chácara, located about $25 \mathrm{~km}$ from Juiz de Fora in an area of ca. 1 ha, in gallery forest of the Rio Cágado.

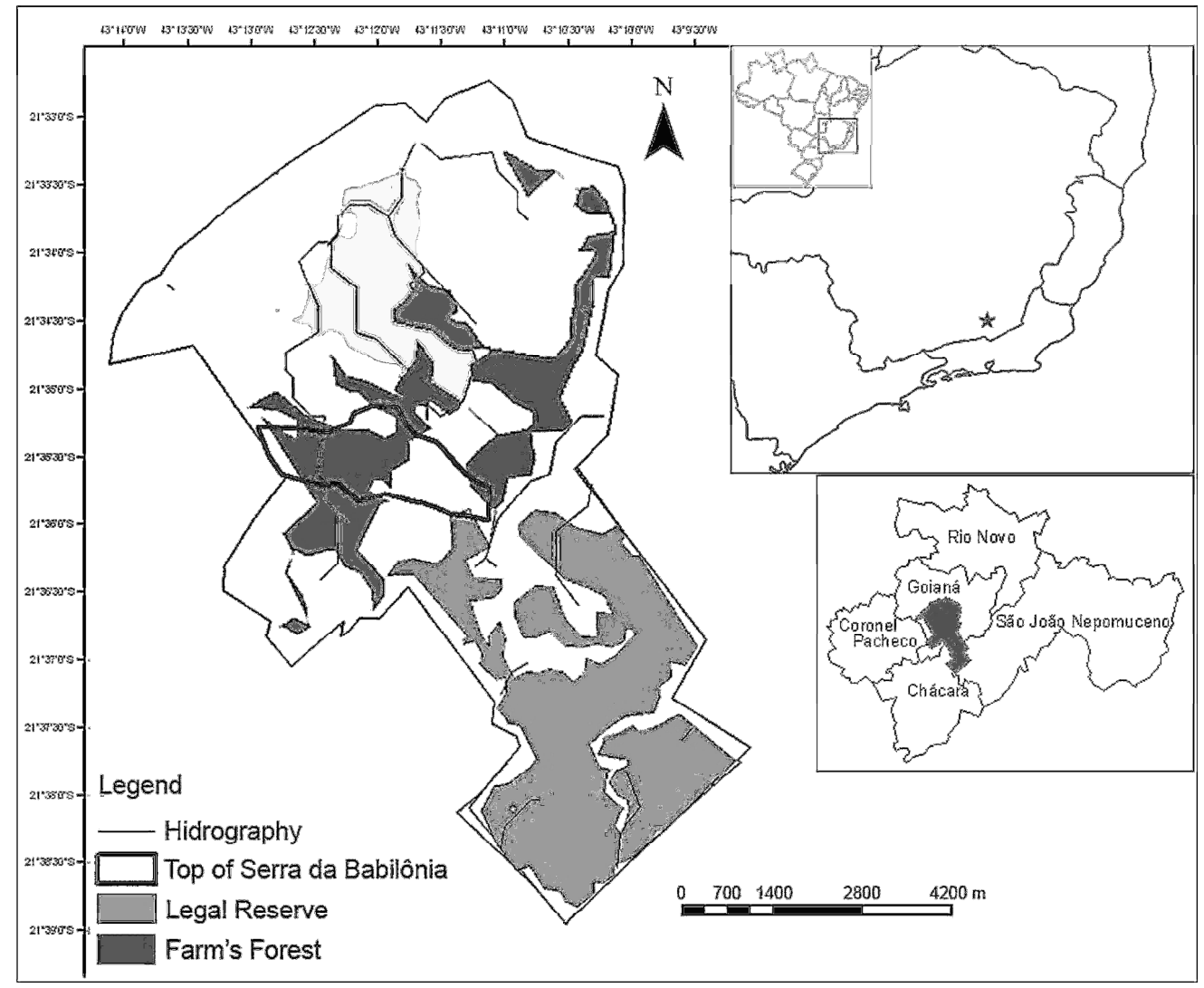

Figure 1. Location of Fazenda Fortaleza de Sant'Anna (Minas Gerais, Brazil) and the surveyed area $\boldsymbol{0}$. Font: modified of PREA (2012).

The plants were photographed and a "Rapid Color Guide" was published by The Field Museum of Chicago (available at: http://fm2.fieldmuseum.org/plantguides/iter_guide.a sp?type $=$ full $\& \mathrm{id}=579 \&$ link=475\%20Epiphytes $\% 20$ of $\% 20$ Sant'Anna.pdf). The collected specimens were herborised according to usual methodology and deposited at the CESJ Herbarium of the Universidade Federal de Juiz de Fora (acronym according to THIERS, 2012). The species were identified by comparison with the collection of the CESJ Herbarium, consultation of specialised bibliography and via consultation of experts in each family. The spelling of species and author names were determined by The International Plants Names Index (www.ipni.org). Infraspecific categories were not considered. The ecological categories of recorded species were classified according to epiphyte-phorophyte relationships based on Benzing (1990).

\section{RESULTS}

Ninety one species of vascular epiphytes were recorded in Fazenda Fortaleza de Sant'Anna, belonging to 44 genera and 12 families (Table 1).

Ferns were represented by 13 species, distributed among four families. Polypodiaceae was the richest family (10 spp.) (Figure 2) and comprised the richest genera: Campyloneurum C.Presl and Microgramma C.Presl (three spp. each), followed by Pleopeltis Humb. \& Bonpl. ex Willd. and Serpocaulon A.R.Sm. (two spp. each). 
Table 1. List of families and species of vascular epiphytes recorded in the Fazenda Fortaleza de Sant'Anna, Zona da Mata of Minas Gerais, Brazil.

\begin{tabular}{|c|c|c|c|}
\hline Families/Species & $\mathrm{CE}$ & Disp. & Voucher \\
\hline \multicolumn{4}{|l|}{ Anemiaceae - 1/1 (Vinicius A.O. Dittrich - CESJ) } \\
\hline Anemia phyllitidis (L.) Sw. & HLA & Anem & 80 \\
\hline \multicolumn{4}{|l|}{ Araceae - 3/7 (Marcus Nadruz - RB) } \\
\hline Anthurium comtum Schott & HLF & Zoo & 56 \\
\hline Anthurium aff. intermedium Kunth & HLF & Zoo & 95 \\
\hline Anthurium pentaphyllum (Aubl.) G.Don & HLC & Zoo & 30 \\
\hline Anthurium scandens (Aubl.) Engl. & HLC & Zoo & 1 \\
\hline Monstera adansonii Schott & HEM & Zoo & 107 \\
\hline Philodendron appendiculatum Nadruz \& Mayo & HEM & Zoo & 106 \\
\hline Philodendron propinquum Schott & HEM & Zoo & 83 \\
\hline \multicolumn{4}{|l|}{ Aspleniaceae - 1/1 (Vinicius A. O. Dittrich - CESJ) } \\
\hline Asplenium martianum C.Chr. & HLC & Anem & 132 \\
\hline \multicolumn{4}{|l|}{ Bromeliaceae - 9/18 (Rafaela C. Forzza - RB) } \\
\hline Acanthostachys strobilacea (Schult. \& Schult.f.) Klotzsch & HLC & Zoo & 135 \\
\hline Aechmea aff. aiuruocensis Leme & HLF & Zoo & 102 \\
\hline Aechmea nudicaulis (L.) Griseb. & HLC & Zoo & 93 \\
\hline Aechmea sp. & HLC & Zoo & 103 \\
\hline Billbergia distachia (Vell.) Mez & HLF & Zoo & 75 \\
\hline Billbergia horrida Regel & HLF & Zoo & 137 \\
\hline Billbergia zebrina (Herb.) Lindl. & HLC & Zoo & 123 \\
\hline Neoregelia farinosa (Ule) L.B.Sm. & HLF & Zoo & 127 \\
\hline Nidularium azureum Leme & HLF & Zoo & 76 \\
\hline Portea petropolitana (Wawra) Mez & HLC & Anem & 134 \\
\hline Quesnelia indecora $\mathrm{Mez}$ & HLF & Zoo & 8 \\
\hline Tillandsia geminiflora Brongn. & HLC & Anem & 130 \\
\hline Tillandsia recurvata (L.) L. & HLC & Anem & 6 \\
\hline Tillandsia stricta Sol. & HLC & Anem & 46 \\
\hline Tillandsia usneoides (L.) L. & HLC & Anem & 105 \\
\hline Vriesea ensiformis (Vell.) Beer & HLF & Anem & 64 \\
\hline Vriesea gigantea Gaudich. & HLF & Anem & 24 \\
\hline Vriesea sp. & HLC & Anem & 47 \\
\hline \multicolumn{4}{|c|}{ Cactaceae - 3/4 (Diego R. Gonzaga - CESJ, Daniela C. Zappi - K) } \\
\hline Hatiora salicornioides (Haw.) Britton \& Rose & HLC & Zoo & 126 \\
\hline Lepismium houlletianum (Lem.) Barthlott & HLC & Zoo & 112 \\
\hline Rhipsalis lindbergiana K.Schum. & HLC & Zoo & 29 \\
\hline Rhipsalis oblonga Loefgr. & HLC & Zoo & 58 \\
\hline \multicolumn{4}{|l|}{ Commelinaceae $-2 / 2$} \\
\hline Commelina sp. & HLA & Aut & 86 \\
\hline Dichorisandra hexandra (Aubl.) Kuntze ex Hand.-Mazz. & HLA & Zoo & 28 \\
\hline \multicolumn{4}{|l|}{ Dryopteridaceae - 1/1 (Vinicius A.O. Dittrich - CESJ) } \\
\hline Polybotrya pilosa Brade & HLC & Anem & 26 \\
\hline \multicolumn{4}{|l|}{ Gesneriaceae - 1/2 } \\
\hline Nematanthus crassifolius (Schott) Wiehler & HLC & Zoo & 113 \\
\hline Nematanthus lanceolatus (Poir.) Chautems & HLC & Zoo & 104 \\
\hline \multicolumn{4}{|l|}{ Marcgraviaceae - 1/1 } \\
\hline Marcgravia polyantha Delp. & HEM & Zoo & 92 \\
\hline \multicolumn{4}{|l|}{ Orchidaceae - 17/35 (Luiz Menini Neto - CESJ) } \\
\hline Campylocentrum brachycarpum Cogn. & HLC & Anem & 2 \\
\hline Campylocentrum crassirhizum Hoehne & HLC & Anem & 12 \\
\hline Campylocentrum wawrae (Rchb.f.) Rolfe & HLC & Anem & 13 \\
\hline Cattleya bicolor Lindl. & HLC & Anem & 66 \\
\hline Dichaea pendula Cogn. & HLC & Anem & 114 \\
\hline
\end{tabular}


Encyclia patens Hook.

Epidendrum armeniacum Lindl.

Epidendrum secundum Jacq.

Eurystyles actinosophila (Barb.Rodr.) Schltr.

Gomesa recurva R.Br.

Isochilus linearis (Jacq.) R.Br.

Leptotes bicolor Lindl.

Maxillaria brasiliensis Brieger

Maxillaria consanguinea Klotzsch

Maxillaria pumila Hook.

Oncidium hookeri Rolfe

Oncidium pumilum Lindl.

Oncidium sp.

Pleurothallis auriculata Lindl.

Pleurothallis grobyi Bateman ex Lindl.

Pleurothallis hygrophila Barb.Rodr.

Pleurothallis hypnicola Lindl.

Pleurothallis luteola Lindl.

Pleurothallis macropoda Barb.Rodr.

Pleurothallis pectinata Lindl.

Pleurothallis saundersiana Rchb.f.

Pleurothallis sp.

Polystachya estrellensis Rchb.f.

Rodriguezia sticta M.W.Chase

Rodriguezia venusta $\mathrm{Rchb}$. $\mathrm{f}$.

Stelis argentata Lindl.

Stelis oligantha Barb.Rodr.

Stelis papaquerensis Rchb.f.

Xylobium variegatum (Ruiz \& Pav.) Mansf.

Zygostates lunata Lindl.

Piperaceae - 1/9 (Daniele Monteiro - RB)

Peperomia alata Ruiz \& Pav.

Peperomia elongata Kunth

Peperomia glabella (Sw.) A.Dietr.

Peperomia martiana Miq.

Peperomia pseudoestrellensis C.DC.

Peperomia rotundifolia (L.) Kunth

Peperomia tenella (Sw.) A.Dietr.

Peperomia tetraphylla (G.Forst.) Hook. \& Arn.

Peperomia sp.

Polypodiaceae - 4/10 (Vinicius A.O. Dittrich - CESJ)

Campyloneurum acrocarpon Fée

Campyloneurum cf. austrobrasilianum (Alston) de la Sota

Campyloneurum nitidum (Kaulf.) C.Presl

Microgramma percussa (Cav.) de la Sota

Microgramma squamulosa (Kaulf.) de la Sota

Microgramma tecta (Kaulf.) Alston

Pleopeltis astrolepis (Liebm.) E.Fourn.

Pleopeltis desvauxii (Klotzsch) Salino

Serpocaulon catharinae (Langsd. \& Fisch.) A.R.Sm.

Serpocaulon fraxinifolium (Jacq.) A.R.Sm.

$\begin{array}{lll}\text { HLC } & \text { Anem } & 11 \\ \text { HLC } & \text { Anem } & 67 \\ \text { HLF } & \text { Anem } & 9 \\ \text { HLC } & \text { Anem } & 17 \\ \text { HLF } & \text { Anem } & 51 \\ \text { HLC } & \text { Anem } & 109 \\ \text { HLC } & \text { Anem } & 124 \\ \text { HLC } & \text { Anem } & 108 \\ \text { HLC } & \text { Anem } & 49 \\ \text { HLC } & \text { Anem } & 125 \\ \text { HLC } & \text { Anem } & 21 \\ \text { HLC } & \text { Anem } & 45 \\ \text { HLC } & \text { Anem } & 68 \\ \text { HLC } & \text { Anem } & 110 \\ \text { HLC } & \text { Anem } & 87 \\ \text { HLC } & \text { Anem } & 96 \\ \text { HLC } & \text { Anem } & 20 \\ \text { HLC } & \text { Anem } & 71 \\ \text { HLC } & \text { Anem } & 19 \\ \text { HLC } & \text { Anem } & 91 \\ \text { HLC } & \text { Anem } & 94 \\ \text { HLC } & \text { Anem } & 90 \\ \text { HLC } & \text { Anem } & 54 \\ \text { HLC } & \text { Anem } & 5 \\ \text { HLC } & \text { Anem } & 136 \\ \text { HLC } & \text { Anem } & 22 \\ \text { HLC } & \text { Anem } & 41 \\ \text { HLC } & \text { Anem } & 40 \\ \text { HLF } & \text { Anem } & 119 \\ \text { HLF } & \text { Anem } & 138 \\ & & \\ \text { HLC } & \text { Zoo } & 128 \\ \text { HLC } & \text { Zoo } & 116 \\ \text { HLC } & \text { Zoo } & 81 \\ \text { HLC } & \text { Zoo } & 79 \\ \text { HLC } & \text { Zoo } & 18 \\ \text { HLC } & \text { Zoo } & 118 \\ \text { HLC } & \text { Zoo } & 117 \\ \text { HLC } & \text { Zoo } & 115 \\ \text { HLC } & \text { Zoo } & 77 \\ & & \\ \text { HLC } & \text { Anem } & 133 \\ \text { HLC } & \text { Anem } & 78 \\ \text { HLC } & \text { Anem } & 55 \\ \text { HLC } & \text { Anem } & 34 \\ \text { HLC } & \text { Anem } & 7 \\ \text { HLC } & \text { Anem } & 35 \\ \text { HLC } & \text { Anem } & 16 \\ \text { HLC } & \text { Anem } & 60 \\ \text { HLC } & \text { Anem } & 14 \\ \text { HLF } & \text { Anem } & 131\end{array}$

CE: ecological category. HLC: characteristic holoepiphyte; HLF: facultative holoepiphyte; HLA: accidental holoepiphyte; HEM: hemiepiphyte. Disp: dispersal mode - Anem: anemochoric; Zoo: zoochoric. Voucher: D.E.F.Barbosa (deposited in the Herbarium CESJ). The numbers after the family names correspond respectively to numbers of genera and recorded species. The names between parentheses refer to the experts that collaborated with the identification of species and respective herbaria. 


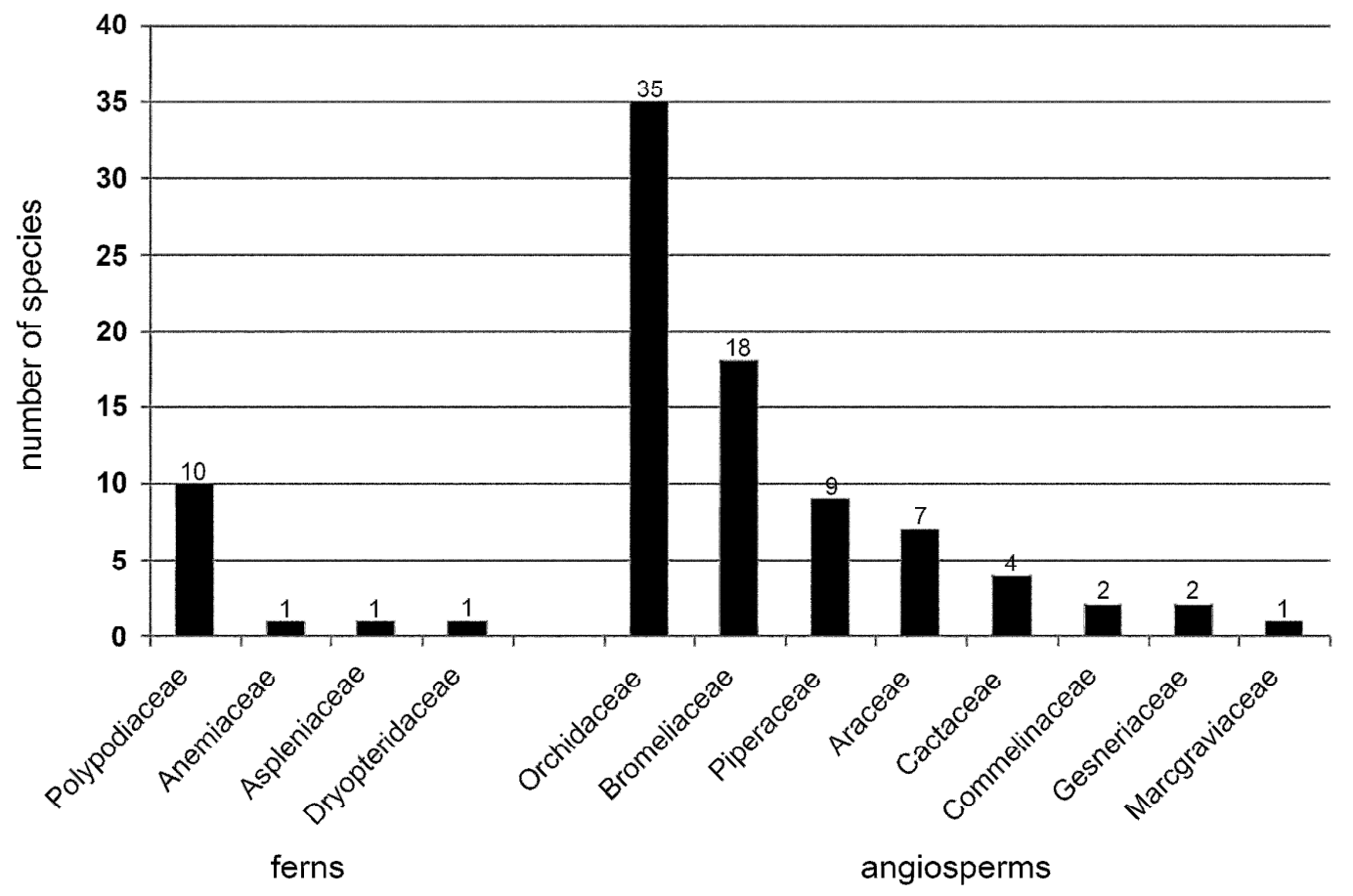

families

Figure 2. Number of species and families of ferns and angiosperms recorded in the Fazenda Fortaleza de Sant'Anna, municipality of Chácara, Minas Gerais, Brazil.

Angiosperms comprised 78 species distributed among eight families: Orchidaceae was the most representative (35 spp.), followed by Bromeliaceae (18 spp.), Piperaceae (nine spp.) and Araceae (seven spp.) (Figure 2). The most representative genera were Peperomia Ruiz \& Pav. (Piperaceae) and Pleurothallis R.Br. s.l. (Orchidaceae) (nine spp. each), Anthurium Schott (Araceae) and Tillandsia L. (Bromeliaceae) (four spp. each), and Aechmea Ruiz \& Pav., Billbergia Thunb., Vriesea Lindl. (Bromeliaceae), Campylocentrum Benth., Maxillaria Ruiz \& Pav. s.l., Oncidium Sw. s.l. and Stelis Sw. (Orchidaceae) (three spp. each), totalling 47 species or slightly more than $60 \%$ of angiosperms and ca. $51 \%$ of all vascular epiphytes recorded in this study.

Rodriguezia sticta M.W.Chase and Stelis oligantha Barb. Rodr. were recorded for the first time in MG. The record of Nidularium azureum Leme (Bromeliaceae) must be highlighted, since it is an endemic species to the region and known only from a few collections from the type-locality (Coronel Pacheco, neighbouring municipality to Chácara), and Rhipsalis oblonga Loefgr. (Cactaceae), recollected after about 100 years without any collection in MG.

Characteristic holoepiphyte was the most frequent ecological category (69 spp., ca. $75 \%$ ) and the most common dispersal syndrome was anemochory (56 spp., ca. 61\%), being more frequent in orchids, ferns and bromeliads of the genera Tillandsia and Vriesea (Table 1).

\section{DISCUSSION}

The five richest families in Fazenda Fortaleza de Sant'Anna (Orchidaceae, Bromeliaceae, Polypodiaceae, Piperaceae and Araceae) include about $86 \%$ of all recorded species, following a pattern observed in the Neotropical Region, in which a few families commonly comprise a high concentration of species (CATLING; LEFKOVITCH, 1989; WAECHTER, 1992; HIETZ; HIETZ-SEIFERT, 1995; DITTRICH et al., 1999; KERSTEN; SILVA, 2001; ARÉVALO; BETANCUR, 2004; GIONGO; WAECHTER, 2004; KERSTEN et al., 2009; MENINI NETO et al., 2009a; BIANCHI et al., 2012). In general, these families are the five most representative in the epiphytic synusia both in the Atlantic Forest (KERSTEN, 2010) as well as globally (MADISON, 1977), occupying however, a different position to that found in FFS. Orchidaceae is frequently the richest family in studies concerning epiphytic flora in the Neotropical Region, followed by Bromeliaceae (DISLICH; MANTOVANI, 1998; 
LINARES, 1999; BUSSMANN, 2001; ARÉVALO; BETANCUR, 2004; ROGALSKI; ZANIN, 2003; GIONGO; WAECHTER, 2004; CERVI; BORGO, 2007; MENINI NETO et al., 2009b).

Although Polypodiaceae is the richest family of epiphytic ferns, both Campyloneurum and Microgramma are seldom highlighted as the most representative genera, since Asplenium or Pleopeltis are often richer (KERSTEN; SILVA, 2001; CERVI; BORGO, 2007; BUZATTO et al., 2008; KERSTEN et al., 2009; MENINI NETO et al., 2009b; GERALDINO et al., 2010), and if Microgramma is cited as the richest genus, it often shares this position with other genera (ROGALSKI; ZANIN, 2003; BREIER, 2005; MANIA; MONTEIRO, 2010). The other recorded genera (Anemia, Polybotrya and Serpocaulon) often have a low or intermediate richness.

According to Carvalho-Silva and Guimarães (2008), Peperomia is predominant in Dense Ombrophilous Forests, and less frequent in Seasonal Forests, in which humidity levels are low, as confirmed by Menini Neto et al. (2009b), who found it to be the most representative genus of epiphytes in a Riverine Forest in the Zona da Mata of MG. However, Cervi and Borgo (2007) found Peperomia to be the most representative genus in a fragment of Seasonal Semideciduous Forest, similar to the results of this study. Surprisingly, Pleurothallis s.l. is the other genus notable for its richness in the Fazenda Fortaleza de Sant'Anna, since it is most speciose in cloud forests (Montane and High Montane Dense Ombrophilous Forests) of the Andes and in the Atlantic Forest (LUER, 1986). Thus, the large number of recorded species in the Fazenda Fortaleza de Sant'Anna is unexpected, suggesting an ombrophilous component in the studied area, probably due to the humidity provided by the Rio Cágado.

In general, the specific richness can be considered low in comparison with studies performed in the Dense Ombrophilous Forest, such as those of Breier (2005) (161 spp.), Petean (2009) (159 spp.) and Blum et al. (2011) (278 spp.), which is an expected result taking into account the climatic factors of this vegetation physiognomy, such as high temperature and humidity, as well as precipitation distributed evenly throughout the year, which favour the occurrence of epiphytic plants. Furthermore, the size of the area might be important in this comparison, since the studies of Breier (2005) and Blum et al. (2011) were performed in larger areas (10.24 and 6.3 ha, respectively), whereas only the area studied by Petean (2009) was $1 \mathrm{ha}$, as in the present study.
If compared with the same type of forest physiognomy (Seasonal Semideciduous Forest), the surveys conducted by Rogalski and Zanin (2003) (70 spp.), Giongo and Waechter (2004) (57 spp.), Breier (2005) (25 spp.), Dettke et al. (2008) (29 spp.), Bataghin et al. (2010) (21 spp.), produced lists with lower richness than that of the Fazenda Fortaleza de Sant'Anna. Even when compared with areas of Mixed Ombrophilous Forest, which have higher humidity levels, which might explain richer floras, the epiphytic flora of Fazenda Fortaleza de Sant'Anna is markedly richer than those areas studied by Dittrich et al. (1999) (74 spp.), Kersten and Silva (2002) (51 spp.), Gaiotto and Acra (2005) (48 spp.) and Buzatto et al. (2008) (44 spp.). However, the richness of Fazenda Fortaleza de Sant'Anna is lower than that observed by Bianchi et al. (2012) (127 spp.) in an area of similar extent (1 ha), reinforcing the theory that ecotones demonstrate a high species richness (KERSTEN, 2010).

Four species are cited in the red list of plants threatened with extinction in MG (BIODIVERSITAS, 2007): Nematanthus crassifolius (Gesneriaceae) and Cattleya bicolor (Orchidaceae) in the category "Vulnerable" (VU); Nidularium azureum (Bromeliaceae) and Pleurothallis pectinata (Orchidaceae) as "Critically Endangered" (CR) (cited as Acianthera pectinata (Lindl.) Pridgeon \& M.W.Chase). Prior to this record, $P$. pectinata was only collected twice in MG, according to Abreu et al. (2007), in the 1950s (in Ferros) and in 1969 (in Juiz de Fora). Since then, there are no records of the species in MG, reinforcing its critical status of conservation. Nidularium azureum is also cited in the Red Book of Brazilian Flora as CR (Forzza et al. 2013), due to reduced area of occurrence and, until this record, only one known population in the municipality of Coronel Pacheco, neighbor to Chácara.

The records of Rodriguezia sticta and Stelis oligantha (Menini Neto et al., 2013), apart from the rediscovery of Rhipsalis oblonga, which has not been collected within the state in the past 100 years, represent an important contribution to the knowledge of MG flora. All three species are considered to be threatened with extinction in the state, due to their restricted distribution, with only a few specimens having been observed (especially the latter two species), and their occurrence in a locality without the protection of a conservation unit.

Rodriguezia sticta was previously known only from Espírito Santo and Rio de Janeiro states, in Seasonal Semideciduous Forest and Dense Ombrophilous Forest (BARROS et al., 2014). It is a 
common species in Fazenda Fortaleza de Sant'Anna, occurring both in the forest interior, in shaded and humid environment near the watercourse and in open environments with anthropogenic intervention, commonly using cultivated loquat (Eriobotrya japonica (Thunb.) Lindl., Rosaceae) as a phorophyte.

Stelis oligantha is previously cited in São Paulo and Rio de Janeiro, occurring typically in Dense Ombrophilous Forest (BARROS et al., 2014). No record of this species was found on the site SpeciesLink (www.splink.org.br), suggesting that it is a rare species. However, its reduced size and difficult observation in the field, allied to a great number of unidentified or misidentified Stelis specimens in herbaria collections (L. MENINI NETO, pers. obs.) do not permit a more accurate conclusion.

Rhipsalis oblonga is found in eastern Brazil, occurring from southern Bahia to São Paulo in gallery forest or Dense Ombrophilous Forest and is absent from MG according to Zappi et al. (2014). However, on the SpeciesLink internet site, there are two specimens from MG in the herbarium of the Smithsonian Museum (US); one collected in 1915 and another without collection date, both lacking a specific locality. Therefore, we confirm the existence of this species in MG, but its rare occurrence must be emphasised, because only one specimen was found in Fazenda Fortaleza de Sant'Anna.

The results concerning ecological categories corroborate the predominance of characteristic holoepiphytes (DITTRICH et al. 1999; KERSTEN; SILVA, 2001; ROGALSKI; ZANIN, 2003; CERVI; BORGO, 2007; DETTKE et al., 2008; MENINI NETO et al., 2009a; BATAGHIN et al., 2010; BONNET et al., 2011; BIANCHI et al. 2012), underlining the importance of this habit for epiphytic plants. Gonçalves and Waechter (2003), Menini Neto et al. (2009a), Geraldino et al. (2010) also emphasise the high frequency of anemochory, corroborating the assertion of Benzing (1990) that it is the most common type of dispersal among epiphytes. The vertical distribution of these plants in the forest confirms the action of wind as the major dispersal agent (MADISON, 1977).

A high biodiversity occurs in the Atlantic Forest, despite the intensive fragmentation of its vegetation, and actions to conserve those remnants are essential. Thus, to provide subsidies to implement these actions it is necessary to perform floristic surveys in this phytogeographic domain, which currently are scarce regarding epiphytic plants, especially in MG, where there are few published studies that address the subject and the epiphytic flora is mostly unknown.

This study shows that a small area of this forest remnant shows a higher specific richness than expected for a Semideciduous Forest in a region with a strong anthropogenic intervention (crops and pasture), increasing the knowledge of the MG flora with two new records ( $R$. sticta and S. oligantha) and the rediscovery of a species that was not collected within the last 100 years ( $R$. oblonga), as well as the collection of $N$. azureum, previously known only from the type-locality.

The existence in the FFS of species threatened with extinction in MG as well as globally (with the presence of the microendemic species, $N$. azureum) highlights the importance of the maintenance of forest remnants in the Zona da Mata of $M G$ and the relevance of surveys in areas not protected by conservation units.

\section{ACKNOWLEDGEMENTS}

We wish to thank Mr. Octaviano Falci Menezes who granted us a license to conduct the study and to the experts who identified the species. We also thank our colleagues Thiago Henrique Fazza dos Santos and Samyra Gomes Furtado who helped and accompanied us on the field expeditions. We thank the Proof Reading Services by the revision of English.

RESUMO: O estudo foi realizado em um remanescente de Floresta Estacional Semidecidual, na Fazenda Fortaleza de Sant'Anna, município de Chácara, Minas Gerais, Brasil (22,0129S, 43,8628W), em uma área aproximada de 1 ha, através de expedições mensais durante o ano de 2012. Foram encontradas 91 espécies de epífitas vasculares, distribuídas em 44 gêneros e 12 famílias. As famílias mais ricas foram Orchidaceae (35 spp.), Bromeliaceae (18 spp.), Polypodiaceae (10 spp.), Piperaceae (nove spp.) e Araceae (sete spp.). Duas espécies foram registradas pela primeira vez para Minas Gerais: Rodriguezia sticta e Stelis oligantha (Orchidaceae). Rhipsalis oblonga (Cactaceae) foi recoletada no estado depois de cerca de 100 anos sem registros. Quatro espécies estão presentes na lista de plantas ameaçadas de extinção em Minas Gerais: Nematanthus crassifolius (Gesneriaceae) e Cattleya bicolor (Orchidaceae) na categoria "Vulnerável" (VU), Nidularium azureum (Bromeliaceae) e Pleurothallis pectinata (Orchidaceae) como "Criticamente em Perigo" (CR). Nidularium azureum também é citado como CR no Livro Vermelho da Flora do Brasil. A maioria das espécies foi classificada como holoepífita característica e a síndrome de dispersão mais frequente foi a anemocoria. 
PALAVRAS-CHAVE: Biodiversidade. Conservação. Fazenda Fortaleza de Sant'Anna. Floresta Atlântica. Município de Chácara.

\section{REFERENCES}

ABREU, N. L.; SANTIAGO, A. L.; MENINI NETO, L. Novos registros de Orchidaceae para a flora do Estado de Minas Gerais, Brasil. Orchidstudium - International Journal of Orchid Study, Poços de Caldas, v. 2 , n. 2-3, p. 37-40, 2007.

ALVES, R. J. V.; KOLBEK, J.; BECKER, J. Vascular epiphyte vegetation in rocky savannas of southeastern Brazil. Nordic Journal of Botany, v. 26, p. 101-117, 2008. http://dx.doi.org/10.1111/j.17561051.2008.00190.x http://dx.doi.org/10.1111/j.0107-055X.2008.00190.x

ARÉVALO, R.; BETANCUR, J. Diversidad de epífitas vasculares en cuatro bosques del sector suroriental de la Serranía de Chiribiquete, Guayana Colombiana. Caldasia, Bogotá, v. 26, n. 2, p. 359-380, 2004.

BARROS, F.; VINHOS, F.; RODRIGUES, V. T.; BARBERENA, F. F. V. A.; FRAGA, C. N.; PESSOA, E. M.; FORSTER, W.; MENINI NETO, L. Orchidaceae. In: Lista de Espécies da Flora do Brasil. Jardim Botânico do Rio de Janeiro, 2014. Disponível em: < http://reflora.jbrj.gov.br/jabot/floradobrasil/FB179 >. Acesso em: 24 jan. 2014.

BATAGHIN, F. A.; BARROS, F.; PIRES, J. S. R. Distribuição da comunidade de epífitas em sítios sob diferentes graus de perturbação na Floresta Nacional de Ipanema, Brasil. Revista Brasileira de Botânica, São Paulo, v. 33, n. 3, p. 501-512, 2010.

BENZING, David. Vascular epiphytes. Cambridge: Cambridge University Press, 1990. 354 p.

BIANCHI, J. S.; BENTO, C. M.; KERSTEN, R. A. Epífitas vasculares de uma área de ecótono entre as Florestas Ombrófilas Densa e Mista, no Parque Estadual do Marumbi, PR. Estudos de Biologia, Curitiba, v. 34, n. 82, p. 37-44, 2012. http://dx.doi.org/10.7213/estud.biol.6121

BIODIVERSITAS. Revisão das listas das espécies da flora e da fauna ameaçadas de extinção do estado de Minas Gerais - Relatório final. v. 2. Belo Horizonte: Fundação Biodiversitas, 2007. 69 p.

BLUM, C. T.; RODERJAN, C. V.; GALVÃO, F. Composição florística e distribuição altitudinal de epífitas vasculares da Floresta Ombrófila Densa na Serra da Prata, Morretes, Paraná, Brasil. Biota Neotropica, Campinas, v. 11, n. 4, p. 141-159, 2011. http://dx.doi.org/10.1590/S1676-06032011000400015

BONNET, A.; CURCIO, G. R.; LAVORANTI, O. J.; GALVÃO, F. Flora epifítica vascular em três unidades vegetacionais do Rio Tibagi, Paraná, Brasil. Rodriguésia, Rio de Janeiro, v. 62, n. 3, p. 491-498, 2011.

BREIER, Tiago Boer. O epifitismo vascular em florestas do Sudeste do Brasil. 2005. 139 f. Tese (Doutorado em Biologia Vegetal), Universidade Estadual de Campinas, Campinas, 2005.

BUSSMANN, R. W. Epiphyte diversity in a tropical Andean forest - Reserva Biológica San Francisco, Zamora-Chinchipe, Ecuador. Ecotropica, Ulm, v. 7, n. 1, p. 43-49, 2001.

BUZATTO, C. R.; SEVERO, B. M. A.; WAECHTER, J. L. Composição florística e distribuição ecológica de epífitos vasculares na Floresta Nacional de Passo Fundo, Rio Grande do Sul. Iheringia, Série Botânica, Porto Alegre, v. 63, n. 2, p. 231-239, 2008.

CARVAlHO-SILVA, M.; GUIMARÃES E. F. Peperomia ciliato-caespitosa M. Carvalho-Silva \& E. F. Guim. (Piperaceae): uma nova espécie para o Brasil. Acta Botanica Brasilica, Feira de Santana, v. 22, n. 2, p. 559$561,2008$. 
CATLING, P. M.; LEFKOVITCH, L. P. Associations of vascular epiphytes in a Guatemalan cloud Forest.

Biotropica, Gainesville, v. 21, n. 1, p. 35-40, 1989. http://dx.doi.org/10.2307/2388439

CERVI, A. C.; BORGO, M. Epífitos Vasculares no Parque Nacional do Iguaçu, Paraná (Brasil). Levantamento Preliminar. Fontqueria, Madrid, v. 55, n. 51, p. 415-422, 2007.

CETEC. Diagnóstico ambiental de Minas Gerais, v. 1. Belo Horizonte: Fundação Centro Tecnológico de Minas Gerais, 1983. 158 p.

DETTKE, G. A.; ORFRINI, A. C.; MILANEZE-GUTIERRE, M. A. Composição e distribuição de epífitas vasculares em um remanescente alterado de Floresta Estacional Semidecidual no Paraná, Brasil. Rodriguésia, Rio de Janeiro, v. 59, p. 859-872, 2008.

DISLICH, R.; MANTOVANI, W. A Flora de epífitas vasculares da Reserva da Cidade Universitária "Armando de Salles Oliveira" (São Paulo, Brasil). Boletim de Botânica da Universidade de São Paulo, São Paulo, v. 17, p. $61-83,1998$.

DITTRICH, V. A. O.; KOZERA, C.; SILVA, S. M. Levantamento florístico dos epífitos vasculares do Parque Barigüi, Curitiba, Paraná, Brasil. Iheringia, série Botânica, Porto Alegre, v. 52, p. 11-22, 1999.

DRUMMOND, Gláucia Moreira; MARTINS, Cassio Soares; MACHADO, Angelo Barbosa Monteiro; SEBAIO, Fabiane Almeida; ANTONIN, Yasmine. Biodiversidade em Minas Gerais: um atlas para sua conservação. $2^{a}$ ed. Belo Horizonte: Fundação Biodiversitas, 2005. 222 p.

DRUMMOND, Gláucia Moreira; MARTINS, Cássio Soares; GRECO, Magda Barcelos; VIEIRA, Fábio. Biota Minas: Diagnóstico sobre a biodiversidade no estado de Minas Gerais - subsídio ao Programa Biota Minas. Belo Horizonte: Fundação Biodiversitas, 2009. 622 p.

FILGUEIRAS, T. S.; NOGUEIRA, P. E.; BROCHADO, A. L.; GUALA, G. F. Caminhamento: um método expedito para levantamentos florísticos qualitativos. Caderno de Geociências, Rio de Janeiro, v. 12 n. 1, p. 3943, 1994.

FORZZA, R. C.; COSTA, A. F.; LEME, E. M. C.; VERSIEUX, L. M.; WANDERLEY, M. G. L.; LOUZADA, R. B.; MONTEIRO, R. F.; JUDICE, D. M.; FERNANDEZ, E. P.; BORGES, R. A. X.; PENEDO, T. S. A.; MONTEIRO, N. P.; MORAES, M. A. Bromeliaceae. In: MARTINELLI, G.; MORAES, M. A. (Eds.). Livro Vermelho da Flora do Brasil. Rio de Janeiro: Instituto de Pesquisas Jardim Botânico do Rio de Janeiro, 2013, p. 315-396.

GAIOTTO, D. F.; ACRA, L. A. Levantamento qualitativo de epífitos da Fazenda Gralha Azul - Fazenda Rio Grande - Paraná. Estudos de Biologia, Curitiba, v. 27, n. 60, p. 25-32, 2005.

GERALDINO, H. C. L.; CAXAMBÚ, M. G.; SOUZA, D. C. Composição florística e estrutura da comunidade de epífitas vasculares em uma área de ecótono em Campo Mourão, PR, Brasil. Acta Botanica Brasilica, Feira de Santana, v. 24, p. 469-482, 2010.

GIONGO, C.; WAECHTER, J. L. Composição florística e estrutura comunitária de epífitos em uma floresta de galeria na Depressão Central do Rio Grande do Sul. Revista Brasileira de Botânica, São Paulo, v. 27, p. 563$572,2004$.

GONÇALVES, C. N.; WAECHTER, J. L. Aspectos florísticos e ecológicos de epífitos vasculares sobre figueiras isoladas no norte da planície costeira do Rio Grande do Sul. Acta Botanica Brasílica, Feira de Santana, v. 17, n. 1, p. 89-100, 2003. 
HIETZ, P.; HIETZ-SEIFERT, U. Composition and ecology of vascular epiphyte communities along an altitudinal gradient in Central Veracruz, Mexico. Journal of Vegetation Science, London, v. 6, n. 4, p. 487498, 1995. http://dx.doi.org/10.2307/3236347

KERSTEN, R. A.; SILVA, S. M. Composição florística e distribuição espacial de epífitas vasculares em floresta da planície litorânea da Ilha do Mel, Paraná, Brasil. Revista Brasileira de Botânica, São Paulo, v. 24, p. 213-226, 2001.

KERSTEN, R. A.; SILVA, S. M. Florística e estrutura do componente epifítico vascular em Floresta Ombrófila Mista Aluvial do rio Barigüi, Paraná, Brasil. Revista Brasileira de Botânica, São Paulo, v. 25, p. 259-267, 2002.

KERSTEN, R. A.; KUNIYOSHI, Y. S.; RODERJAN, C. V. Epífitas vasculares em duas formações ribeirinhas adjacentes na bacia do rio Iguaçu - Terceiro Planalto Paranaense. Iheringia, Série Botânica, Porto Alegre, v. 64, n. 1, p. 33-43, 2009.

KERSTEN, R. A. Epífitas vasculares - Histórico, participação taxonômica e aspectos relevantes, com ênfase na Mata Atlântica. Hoehnea, São Paulo, v. 37, n. 1, p. 9-38, 2010. http://dx.doi.org/10.1590/S223689062010000100001

LINARES, E. L. Diversidad y distribución de las epífitas vasculares en un gradiente altitudinal en San Francisco, Cundinamarca. Revista da Academia Colombiana de Ciências, Bogotá, v. 33, supl. esp., p. 133139, 1999.

LUER, Carlyle August. Icones Pleurothallidinarum I. Systematics of the Pleurothallidinae (Orchidaceae). Monographs in Systematic Botany from the Missouri Botanical Garden, 15. Missouri: Missouri Botanical Garden, 1986. 81 p.

MADISON, M. Vascular epiphytes: their systematic occurrence and salient features. Selbyana, Sarasota, v. 2, n. 1, p. 1-13, 1977.

MANIA, F. L.; MONTEIRO, R. Florística e ecologia de epífitas vasculares em um fragmento de floresta de restinga, Ubatuba, SP, Brasil. Rodriguésia, Rio de Janeiro, v. 61, n. 4, p. 705-713, 2010.

MENINI NETO, L.; FORZZA, R. C., ZAPPI, D. Angiosperm epiphytes as conservation indicators in forest fragments; a case study from southeastern Minas Gerais, Brazil. Biodiversity and Conservation, Madrid, v. 18, n. 14, p. 3785-3807, 2009a. http://dx.doi.org/10.1007/s10531-009-9679-2

MENINI NETO, L.; FURTADO, S. G.; ALVES, F. E.; BARBOSA, D. E. F.; BASÍLIO, G. A.; DELGADO, C. N.; SALIMENA, F. R. G. Novos registros de Orchidaceae epífitas para o estado de Minas Gerais, Brasil. Orquidário, Rio de Janeiro, v. 27, n. 3, p. 77-86, 2013.

MENINI NETO, L.; MATOZINHOS, C. N.; ABREU, N. L.; VALENTE, A. S. M.; ANTUNES, K.; SOUZA, F. S.; VIANA, P. L.; SALIMENA, F. R. G. Flora vascular não-arbórea de uma floresta de grota na Serra da Mantiqueira, Zona da Mata de Minas Gerais, Brasil. Biota Neotropica, Campinas, v. 9, n. 4, p. 149-161, 2009b. http://dx.doi.org/10.1590/S1676-06032009000400015

MYERS, N.; MITTERMEIER, R. A.; MITTERMEIER, C. G.; FONSECA, G. A. B.; KENT, J. Biodiversity hotspots for conservation priorities. Nature, London, v. 403, p. 853-858, 2000.

http://dx.doi.org/10.1038/35002501

PETEAN, Marise Pim. As epífitas vasculares em uma área de Floresta Ombrófila Densa em Antonina, PR. 2009. 75 f. Tese (Doutorado em Engenharia Florestal), Universidade Federal do Paraná, Curitiba, 2009. 
PREA (PROGRAMA DE EDUCAÇÃO AMBIENTAL). Fazenda Fortaleza de Sant'Anna: trilhando um caminho para a conservação (Relatório Técnico). Juiz de Fora: Programa de Educação Ambiental. 2012. 65 p.

RIBEIRO, M. C.; METZGER, J. P.; MARTENSEN, A. C.; PONZONI, F. J.; HIROTA, M. M. The Brazilian Atlantic Forest: how much is left, and how is the remaining forest distributed? Implications for conservation. Biological Conservation, Boston, v. 142, p. 1141-1153, 2009. http://dx.doi.org/10.1016/j.biocon.2009.02.021

ROGALSKI, J. M.; ZANIN, E. M. Composição florística de epífitos vasculares no estreito de Augusto César, Floresta Estacional Decidual do Rio Uruguai, RS, Brasil. Revista Brasileira de Botânica, São Paulo, v. 26, p. 551-556, 2003.

STEHMANN, João Renato; FORZZA, Rafaela Campostrini; SALINO, Alexandre; SOBRAL, Marcos; COSTA, Denise Pinheiro; KAMINO, Luciana Hiromi Yoshino. (Orgs.). Plantas da Floresta Atlântica. Rio de Janeiro: Jardim Botânico do Rio de Janeiro, 2009. 516 p.

THIERS, B. [continuously updated]. Index Herbariorum: A global directory of public herbaria and associated staff. New York Botanical Garden's Virtual Herbarium. 2012. Disponível em: < http://sweetgum.nybg.org/ih/ > Acesso em: 01 nov. 2012.

VALVERDE, O. Estudo regional da Zona da Mata de Minas Gerais. Revista Brasileira de Geografia, Rio de Janeiro, v. 20, n. 1, p. 1-82, 1958.

WAECHTER, Jorge Luiz. O epifitismo vascular na planície costeira do Rio Grande do Sul. 1992. 162 f. Tese (Doutorado em Ecologia e Recursos Naturais), Universidade Federal de São Carlos, São Carlos, 1992.

WERNECK, M. S.; ESPÍRITO-SANTO, M. M. Species diversity and abundance of vascular epiphytes on Vellozia piresiana in Brazil. Biotropica, Gainesville, v. 34, n. 1, p. 51-57, 2002. http://dx.doi.org/10.1646/0006-3606(2002)034[0051:SDAAOV]2.0.CO;2 - http://dx.doi.org/10.1111/j.17447429.2002.tb00241.x

ZAPPI, D.; TAYLOR, N.; SANTOS, M. R.; LAROCCA, J. Cactaceae. In: Lista de Espécies da Flora do Brasil. Jardim Botânico do Rio de Janeiro, 2014. Disponível em: < http://reflora.jbrj.gov.br/jabot/floradobrasil/FB1713 >. Acesso em: 24 jan. 2014. 